\title{
IMPROVING STUDENTS IN WRITING SKILL BY USING SCRAMBLED PICTURE IN NARRATIVE TEXT
}

\author{
Arum Yunita Puspitasari (Corresponding Author) \\ Siane Herawati (Corresponding Author) \\ SDN 1 SITIREJO KAB MALANG \\ e-mail : arumyunitapuspitasari@gmail.com
}

\begin{abstract}
Writing is one of four basic skills that students in junior high school have to learn. While a writing is complicated because there are many aspects such as mechanics, vocabulary and grammar, and writing activities.The students must be able to combine word and sentences grammatically into written text. Based on junior high school curriculum which is designed by Indonesia government, the students should understand and create various functional texts, monologues and essays in the form of descriptive, procedure, report, recount and narrative text. The student should be able to develop their skill to express the meaning and the structure of the text. In this research the researcher founds some problem faced by the students in the eighth grade of SMP Islam Al Amin Malang. They don't know how to start writing and organize their ideas. Second, they still had difficulties to understand conjunction and punctuation, third they were also low of vocabulary mastery. Beside that the teacher still used conventional technique to teach writing, especially in narrative text.The researchers used classroom action research. In this research, the researcher conducted one cycle in implementing the method by using Scrambled Picture. The researcher conducted in one cycle because in cycle one the criteria of success had been achieved. The success of this research is influenced by two factors; the researcher's factor and the student's factor. The researcher's factor was the researcher's classroom management and the researcher's explanation. The students also happy to used Scrambled Picture in writing narrative text during teaching and learning process.
\end{abstract}

Key Words: Improving, scramble, narattive

Kirszner and Mandel (2008) state that writing needs some steps such as planning, organizing, drafting, revising, and editing. Writing is complicated because there are many aspects such as mechanics, vocabulary and grammar. In writing activities, students must be able to combine word and sentences grammatically into written text. Narrative text can develop for student's imagination about the legend, myth and short story. Those are examples of narrative texts when the student writes a narrative, they recount a story, describe the character and express the feeling. However, to describe the character and express the student's feeling made the students confuse to write narrative text. Based on the researcher's observation in SMP Islam Al-Amin Malang, gets some problems faced by them: (1) the students did not know how to start writing and organize their ideas, (2) the student still had difficulties to understand conjunction and punctuation. (3) They were also low in vocabulary mastery. Besides that, the teacher still used a conventional technique to teach writing, especially in narrative text.

There are so many techniques that can be applied to make students easier to create narrative text. One of the techniques to improve students writing skill especially in writing narrative text by using a picture. A picture helps the students to associate their imagination with their life experience. In this case, the writers choose Scrambled Pause it encourages students to have more imagination about what they will write. Scrambled 
Pictures are puzzle picture which is display randomly. The objective was to solve the puzzle by moving to the correct locations to form an image of the original picture. According to Rebecca (2003), a narrative text is a text, which relates a series of logically, and chronologically related events that are caused or experienced by factors. reaches its high point in the middle. The ending resolves the problem.

The research problem is how can Scrambled Picture improve students' ability in writing narrative text to the eighth grade of SMP Islam Al Amin Malang?

Based on the statement of the problems, the aim of this study is "to identify the students' improvement in writing skill by using Scrambled Picture in narrative text among eighth graders of SMP Islam Al Amin Malang”.

\section{Subject of the Study}

The subject of this research is the eighth graders of Junior High School in SMP Islam Al Amin Malang, especially the students of 8 class $8 \mathrm{C}$. There are 40 students in the classroom. The class consists of 20 male and 20 female students. The researcher takes this class because the students' ability is relatively similar.

\section{Research Procedure}

The researcher uses Kemmis and Taggart model to be applied in this research. This model mentions that if criteria of success in cycle I do not achieve, the researcher should continue to the next cycle. The cycle I consist of some steps, there are planning, implementing, observing and reflecting. Meanwhile, cycle II is the improvement of the cycle I.

\section{Implementing}

The researcher uses 4 meetings to conduct cycle I and every meeting consist of 90 minutes. The implementation step stages were divided into four sections. These are opening section, main activity section, whilst section, and closing section. In implementing the scrambled picture, the students write a narrative text the story with a scrambled picture on the letter.

The researcher and the collaborator collected data in teaching learning process during the implementation of the Scrambled Picture. The researcher observes the student's behavior to know they are interested or not in a teaching-learning process.

\section{Research Instrument}

To collect the data, some instruments were used by the researcher, they were: Observation, Test, and Questionnaire.

Direct observation used to know the phenomena or get the information. This observation will be divided into two steps: before and while using the method. The observation conducted to know the real condition of class, here the researcher will observe the teacher's method, students' activeness, and achievements.

The test uses to know the result of using Scrambled Picture in teaching English Writing. The researcher conducted the post-test for the students by giving a score of their performance. The research used a scoring rubric for scoring the students' writing skill. This test should be the key to decide whether a research success or not.

The questionnaire uses to collect the information from students' responses after using Scrambled Picture toward writing skill in narrative text. Kunandar (2013) stated 
that a questionnaire is an efficient way to collect data or information from the students. The researcher gives 10 questions to collect the data toward student's responses after using Scrambled Picture that states in multiple choices. The strategy will be successful if $80 \%$ of the whole students interested during the teaching-learning process. In addition, each number has five choices.

\section{Research Findings}

In this research, the researcher conducted one cycle in implementing the method by using Scrambled Picture. It was done because in cycle one the criteria of success had been achieved.

\section{Preliminary Study}

The preliminary study was conducted on August 12th, 2018. The researcher interviewed the English teacher about the problem of the students in a teaching-learning process in a class. Based on the data from the English teacher, the students did not know how to start writing and organize their ideas. Second, the students still had difficulties to understand conjunction and punctuation. They were also low in vocabulary mastery. Beside that the teacher still used a conventional technique to teach writing, especially in narrative text.

\section{Cycle 1}

Cycle 1 was done on September 12th, 2018 to September 19th, 2018. This cycle has four meetings, three meetings to give materials and implement Scrambled Picture and the fourth meeting the researcher did the post-test to know whether the student's writing narrative text increased or not. Each meeting has three steps in a teachinglearning process. The first is pre-activities, second is whilst-activities, and the last is post-activities.

\section{Planning}

The researcher prepared a lesson plan before doing the research. A lesson plan was needed to guide the researcher in teaching- learning process and to provide good teaching during the implementation of the method. The lesson plan included the researcher and the students. Before making the lesson plan, the researcher consulted with the teacher as a collaborator. The lesson plan used in this research was based on the syllabus from the school (Curriculum 2013).

The researcher used a story to stimulate students' background knowledge related with the topic. The researcher also prepared instruments in Cycle 1. The instruments were: writing test, questionnaire and observation checklist. The writing test was writing narrative text based on the Scrambled Picture. The questionnaire was used to know the students' perception toward implementation Scrambled Picture in teaching learning process. While observation checklist was used to know the students' attitude in the classroom during implementing Scrambled Picture. The researcher collaborated with the teacher in observation checklist.

Implementation

The implementation of the action by using Scrambled Picture was conducted on September 12th, 2018 up to September 20th, 2018. The researcher conducted four meetings in the cycle, and each meeting has three activities; they are pre-teaching, whilst-teaching, and post-teaching and it was done in 80 minutes. 


\section{Meeting 1 (September, 12th 2018)}

\section{Pre-teaching}

First, the researcher started the lesson by greeting, asked the student's condition "How are you?", checked the attendance list, asked the students early to learn. Then, the researcher explained the topic that will be learned. Before starting to learn, the researcher gave brainstorming about what they are doing last night. Some students respond to questions given by the researcher.

\section{Whilst-teaching}

In this stage, the researcher explained about simple past tense. The first explanation was about a definition of simple past tense, social function, generic structure, and language feature. For checking the students understanding, the researcher asked the students to do the task by writing the answering the blackboard one by one. Some students confused about past tense and could answer a few questions. Second, the researcher explained about narrative text. Then the researcher gave an example of narrative text. The researcher explained about language feature. Then the researcher asked the students to gather in their group. There were five groups. The groups of the students should do the worksheet about narrative text. The researcher asked the students to analyze a narrative text based on the text that the researcher gave.

The groups started to do their worksheet together. There were noisy during the discussion. During the discussion, the researcher observed every group for knowing the problem faced by the students.

\section{Post-teaching}

In this activity, the researcher reviewed the material and gave feedback for the students on how they analyze the text. The researcher asked some difficulties when the students learned about narrative text. Some students answered if they feel confused about the structure of using simple past tense. Before closing the meeting, the researcher made a conclusion about narrative text and the students gave homework to find a narrative text. Then, the researcher closed the meeting.

\section{Meeting 2 (September,15th 2018) Pre-Teaching}

First, the researcher started the lesson by greeting, asking the student's condition, checking the attendance list, and asked the students easily to learn. Then, the researcher reviewed the material learned in the last meeting to refresh their memory. The students still remember what the material in the last meeting.

\section{Whilst teaching}

In this stage, the researcher told the students about Scrambled Picture including the procedure to use Scrambled Picture. Then the researcher asked the students to gather in their group. There were five groups. The groups of the students should do the worksheet about narrative text. There were very noisy during the group because some students still confuse what do with the picture. The researcher asked the students to make a narrative text based on the Scrambled Picture that the researcher gave. The students arranged the picture in order, after that they started to write the text carefully. Then the students work with their group, two members from every group come in front 
of the class to present their worksheet, and the other friend gave some comment. When the students present their worksheet in front of the class, there are some students who feel embarrassed.

\section{Post-teaching}

In this activity, the researcher concluded the material about narrative text and asked the students difficulties during the implementation of technique Scrambled Picture. The student answer very enjoyed with the implementation of technique Scrambled Picture. Then, the researcher closed the meeting.

Meeting III(September,19th 2018)

\section{Pre-Teaching}

First, the researcher started the lesson by greeting, asking the student's condition, checking the attendance list, and asking the students easily to learn. Then, the researcher reviewed the material learned in the last meeting to refresh their memory. The students still remember what the material in the last meeting.

\section{Whilst teaching}

In this stage, the researcher told the students about Scrambled Picture including the procedure to use Scrambled Picture. Then the researcher asked the students with their group. There were five groups. The groups of the students should do the worksheet about narrative text. The researcher asked the students to make a narrative text based on the Scrambled Picture that the researcher gave. The students arranged the picture in order first then after that they started to write the text carefully. After the students worked with their group, one student from every group come in front of the class to present their worksheet, and the other friend gave some comments. When the students present their worksheet in front of the class, there are some students still feel embarrassed.

\section{Post-teaching}

In this activity, the researcher concluded the material about narrative text and asked the students difficulties during the implementation of technique Scrambled Picture. Then, the researcher closed the meeting.

\section{Meeting IV (September, 20th 2018)}

\section{Pre-teaching}

First, the researcher started the lesson by greeting, asked the student's condition, checked the attendance list, and asked the students to prepare for post-test.

\section{Whilst teaching}

In this stage, all of the students took the post-test. The researcher gave the students fifteen minutes to prepare their post-test. The researcher gave the students Scrambled Picture and paper. Then, the students tried to arranged and started to write a story based on the picture. The researcher gave eighty minutes to write.

Post-teaching 
After the students finished, the researcher made a conclusion about the material and gave the students motivation to learn English more. Then, the researcher closed the meeting.

Observing

The researcher observed the students writing ability score in post-test. After doing the treatment, the researcher gave the students post-test in the fourth meeting. The teacher as the collaborator helped the researcher to manage the classroom. When the researcher did the post-test, the teacher as collaborator sat down behind the class. Before doing the test, the researcher gave instruction and the students followed the instruction.

The researcher explained the material in the first meeting and did method in the second and third meeting. The researcher gave the students opportunities to ask related to the material. When the researcher explained, some students did not give attention. Before doing the treatment, the researcher guided the students and most of the students paid attention. However, some students did not pay attention and were busy talking with their friend. Based on the result from the observation checklist some students did not give attention to the teacher's explanation about the material and they talked with their friend.

After scoring the researcher found from 40 students in the classroom there were three students got to score 60, two students got to score 65, six students got to score 70, nine students got to score 75 , seven students got to score 80 , seven students got to score 85 , six students got to score 90 . There were 10 students of 40 students got to score under 75 from and the percentage was $27.5 \%$. There were 30 students of 40 got to score up to 75 and the percentage was $72.5 \%$. Based on this result, it was concluded cycle one was successful because of the criteria of success is $72 \%$ for the score writing skill from the whole of students in the class. (see Table 3.1)

The researcher and the English teacher as collaborator observed the student's attitude during implementation Scrambled Picture. The students in the class were very noisy and some students gave attention to the teacher's instruction. When the researcher asked the students to discuss with their group, some students did not give a contribution to the group. It is shown from the students' activeness in asking and giving the opinion. Observation checklist was successful because the result showed $75 \%$ from $75 \%$ criteria of success.

\section{Discussion}

Based on the result of the cycle I, there is an improvement of student's ability in writing a narrative text after implementing the Scrambled Picture. The improvement of the student's ability in writing by using Scrambled Picture was supported previous research by Yunita (2017). First, Yunita (2017) found that the students who are taught by using Scrambled Picture were braver when they were given an idea in the teaching and learning process. Second, the students could write easily after doing teamwork. The weakness of her research is the students still could not manage the time in discussion. They are still got difficulty if they give an idea they were shy and afraid to ask the lesson to the teacher. In the teaching and learning process, sometimes the groups 
were shy to come forward. So, the teacher must ask one of the groups to present their task.

The differences between this research and the previous research are the researcher focused on solving student's difficulties in brainstorming their ideas in writing narrative text by using Scrambled Picture in VIII C of SMP Islam Al-Amin Malang. Meanwhile, the similarity was the result of this research. This research found that Scrambled Picture could improve the students in writing.

The success of this research is influenced by two factors; the researcher's factor and the student's factor. The researcher's factor was the researcher's classroom management and the researcher's explanation. The first, classroom management is one of the important aspects of the process of teaching. It is supported by Froyen and Iverson(1999) who stated that creating for effective classroom management is essential for the students. The researcher could control the students in participating to write narrative text. The researcher also guided the students and explained them clear instruction. It made the students easier to follow the strategy to write a narrative text.

Second, the researcher's explanation. The researcher's explanation was an important aspect of the success of this research. It confirms the theory by Brown (1978) who stated that the clear explanation is necessary to present the materials in a way that allows the students to develop an understanding about the topic. The teacher explained the material clearly and the teacher's voice was louder. It made the students easier to listen to the teacher's explanation and made them easier to understand the materials during the teaching and learning process. It is proven by more than half of the students can achieve the minimum score.

Meanwhile, the student's factors are student's attention, participation and interest. The student's attention to the teacher's explanation has some effects on their understanding of the narrative text, generic structure of the narrative text, and the verb of past tense. It makes the students having a better understanding of the steps on Scrambled Picture. The student's participation was also important in this research. According to Davis (1999), the students thought that participation was essential to their own learning. The students actively participated in the discussion to share their opinion and confirms their understanding among each other. It made them learn how to make a narrative text well. It also supported by the theory of Hill (2012) who stated that an important mode of feedback is the reaction of feedback. The students made corrections between themselves. It made them developing their understanding of good writing and being them more confident in writing.

The students were also more interested in writing. The students thought that writing using picture was better than the conventional method. It confirms the theory by Quinn (2004) who stated that Scrambled Picture is a good strategy to make students briefer to express themselves to express their ideas and generate it with each other.

The finding of the research also in line with the theory of Bakharudin (2012) who state that the procedure of teaching writing by using Scrambled Picture media. First, teachers prepare an image, then students in each group work on the problems and search for images for image matching arrangement previously had been in a random drawing in such a way. Then students are required to be able to compose images answers that have been available in the allotted time. Then create a story based on the images. After completion of work on the problems, the results of student work collected and carried. The students who are taught by using Scrambled Picture could explore their ideas well. By arranging the picture, the students are helped to imagine and find new 
ideas in writing a narrative text. It could be seen from the result of the test that the students could write a creative narrative text.

During the process, there was cooperation in the process of writing narrative text among the students while using the Scrambled Picture. This means that there is an implementation of cooperative learning in which one of the strategies is Scrambled Picture (Kagan and Kagan, 2000).

However, Scrambled Picture had weaknesses when it is applied in the classroom. Sometimes, the students were noisy during the discussion because they still confused with the media. In another hand, Scrambled Picture cannot be used in large groups because it made the students depend on the other students. The use of Scrambled Picture also made some students not participate in groups. Even though Scrambled Picture had weaknesses, it was an effective way to be used in writing narrative text. It can be seen from the result showed that the mean score of the students' posttest was higher if it was compared with the mean score from the teacher. The mean score of the students in writing a narrative text before giving treatment was 62,5. Then, after giving treatment by using Scrambled Picture, there was a good improvement. The result showed that the means score in the writing narrative text was 77,5. It meant that Scrambled Picture can be used as an effective way of teaching writing.

Furthermore, the researcher conducted in cycle 1 because of the result of the writing test, questionnaire and observation checklist had been achieved in the criteria of success. In the other hand, the students were happy to use Scrambled Picture in writing narrative text because it made the students more active in the learning process. This research will also be successfully used in other classes if the students' ability in that class was the same or more than the students who are the subjects in this study.

\section{Conclusion}

Based on the finding in the previous chapter, the implementation of Scrambled Picture gave a positive effect on students' writing achievement. The result showed that the mean score of the students' posttest was higher if it was compared with the mean score from the teacher. The mean score of the students in writing a narrative text before giving treatment was 62,5. Then, after giving treatment by using Scrambled Picture, the result showed that the means score in the writing narrative text was 77,5.

This research was conduct on only one cycle. The success of this research is influenced by two factors; the researcher's factor and the student's factor. The researcher's factor was the researcher's classroom management and the researcher's explanation. The students also happy to used Scrambled Picture in writing narrative text during teaching and learning process.

\section{REFERENCES}

Aen, K.2010.The Effectiveness of Using Scrambled Pictures to Improve The Students' Ability In Speaking Narrative Text.Walisongo State Institute For Islamic Studies Semarang retrieved from eprints.walisongo.ac.id/3397/1/63411055.pdf(Accessed on January $6^{\text {th }} 2018$ ) 
Anderson, M. \& Anderson, K. 2003. Text Types in English 2.South Yarra: Macmillan Education Australia PTY LTD.

Arifin, Z. 2012. PenelitianPendidikan - Metodedan Paradigma Baru. Bandung: PT. RemajaRosdakarya.

Bakharudin. Model-model Pembelajaran Terbaru. retrieved from http://www.bakharudin.net/2012/11/model-model-pembelajaran-terbaru.html (Accessed on December 10 ${ }^{\text {th }} 2018$ )

Brown, G. (1978). Lecturing and Explaining. London: Methuen.

Cohan, S. 2001. Telling Stories. a Theoretical Analysis of Narrative Fiction. London: Taylor and Francis E-Library.

Davis, B. (1999). Cooperative Learning: Students Working in Small Groups, New York: International Journal of the center for Teaching and Learning vol. 10(2)195-198.

Froyen, L. A., and Iverson, A.M. (1999). School Wide and Classroom Management: The Reflective Educator-Leader (3rd ed.). Upper Saddle River,NJ: Prentice-Hall.

Hill, C. (2011). Peer Editing: A Comprehensive Pedagogical Approach to Maximize Assessment Opportunities, Integrate Collaborative Learning, and Achieve Desired Outcomes. Nevada Law Journal, 11 Nev. L.J. 667, 1-22.

Kagan, S., \& Kagan M. (2000). Kagan Cooperative learning. New York: Kagan Publishing.

Kirszner and Mandel. 2008. Advantage Books: The Pocket Wadsworth Handbook. California. Wadsworth Publishing

Johnson, A. 2005. Short Guide to Action Research, A, 3rd Edition. Mankato: Minnesota State University,

Latief. MA. 2011. Research Methods on Language Learning: An Introduction. Malang: UniversitasNegeri Malang (UM Press)

Mc. Taggart, R And Kemmis, S. 1988. The Action Research Planner. Melbourne. Deakin University

Prayoga, D. 2016. Using Scrambled Picture to Improve Students' Writing Ability in Procedure Text in SMPN 1 Gondanglegi.Unpublished Thesis University of Kanjuruhan Malang

Quinn, K. (2004). Cooperative Learning Strategies. New York: Winnipeg 
Richard, J. 2002. Methodology in Language Teaching. An Anthology of Current Practice. New York: Cambridge University Press.

Richard, J. 1990. Longman Dictionary of Applied Linguistics. Hong Kong. Longman Group

Rebecca, J. L. 2003. A Critical Handbook of Children's Literature. Massachuset: Pearson Education, Inc.

Tanum, Sutarsyah, and Hasan: 2013. The Effectiveness of Using Scrambled Pictures in Increasing Students' Reading Ability. retrieved fromhttps://media.neliti.com/media/publications/213489-none.pdf(Accessed on March $17^{\text {th }}$ 2018)

Wallace, M. 1998. Action Research for Language Teacher. Singapore: Cambridge University Pres

Widdowson.H. Definition of Writing Ability retrieved fromhttp://teachingenglishonline.net, (Accessed on January $10^{\text {th }} 2018$ )

Yunita. 2017. Improving Students' Writing Ability in Narrative Text by Using Scrambled Pictures at Eight Grade Students of SMP PGRI 2 Karangmalang Sragen in The Academic Year 2015/2016. retrieved from eprints.iainsurakarta.ac.id/652/1/19.\%20Ria\%20Yunita.pdf (Accessed on January $6^{\text {th }} 2018$ ) 